OPEN ACCESS

Influence of Phosphorus on Current Efficiency in Aluminum Electrolysis at Different Current Densities

To cite this article: Rauan Meirbekova et al 2017 J. Electrochem. Soc. 164 E161

View the article online for updates and enhancements. 


\title{
Influence of Phosphorus on Current Efficiency in Aluminum Electrolysis at Different Current Densities
}

\author{
Rauan Meirbekova, ${ }^{\text {a,b,z }}$ Geir Martin Haarberg, ${ }^{\text {b,* Jomar Thonstad, }}$, ,** \\ and Gudrun Saevarsdottir ${ }^{\mathrm{a}}$
}

${ }^{a}$ School of Science and Engineering, Reykjavik University, 101 Reykjavik, Iceland

${ }^{b}$ Department of Materials Science and Engineering, NTNU, NO-7491 Trondheim, Norway

\begin{abstract}
Many factors may contribute to loss of current efficiency (CE) in aluminum reduction and one of them is a presence of impurities. In this work, the effect of phosphorus on CE is studied in a laboratory cell at different current densities. Due to a growing trend toward higher amperage in retrofitted industrial cells, a study is performed both at a representative industrial current density $(0.8$ $\left.\mathrm{A} / \mathrm{cm}^{2}\right)$ and at a high current density $\left(1.5 \mathrm{~A} / \mathrm{cm}^{2}\right)$. More resolution was obtained at phosphorus levels comparable to typical industrial concentration in aluminum reduction cell $(0-220 \mathrm{mg} / \mathrm{kg})$. It is shown that the effect of phosphorus on the CE is more significant at high current density. Trend lines for the whole concentration range btw. 0 and $630 \mathrm{mg} / \mathrm{kg}$ showed a decrease of $1.1 \%$ in CE per 100 $\mathrm{mg} / \mathrm{kg}$ for the high current density and $0.67 \%$ per $100 \mathrm{mg} / \mathrm{kg}$ at the low current density. The detrimental effect was more pronounced for relatively low phosphorus contents up to $220 \mathrm{mg} / \mathrm{kg}$. A trend line for that smaller range revealed a reduction of $2.5 \%$ per 100 $\mathrm{mg} / \mathrm{kg}$ of phosphorus at $1.5 \mathrm{~A} / \mathrm{cm}^{2}$, while at $0.8 \mathrm{~A} / \mathrm{cm}^{2}$ a reduction of $0.92 \%$ per $100 \mathrm{mg} / \mathrm{kg}$ of phosphorus was obtained. This indicates that increasing amperage in retrofitted cells may amplify the detrimental effect of impurities on the current efficiency. (c) The Author(s) 2017. Published by ECS. This is an open access article distributed under the terms of the Creative Commons Attribution Non-Commercial No Derivatives 4.0 License (CC BY-NC-ND, http://creativecommons.org/licenses/by-nc-nd/4.0/), which permits non-commercial reuse, distribution, and reproduction in any medium, provided the original work is not changed in any way and is properly cited. For permission for commercial reuse, please email: oa@electrochem.org. [DOI: 10.1149/2.0941707jes] All rights reserved.

Manuscript submitted March 6, 2017; revised manuscript received April 21, 2017. Published May 23, 2017.

Aluminum is produced from alumina by electrolysis in the HallHéroult process which is energy intensive, requiring around $13 \mathrm{kwh} / \mathrm{kg}$ of produced metal. ${ }^{1}$ As a result, power consumption is one of the most important operation cost drivers of an aluminum smelter. Current efficiency (CE) in aluminum reduction is the percentage of the electric current which actually produces aluminum. ${ }^{2}$ The CE in modern HallHeroult cells can be as high as $96 \%$, but even a $1 \%$ reduction in $\mathrm{CE}$ means millions of dollars in loss. Managing the $\mathrm{CE}$ at these high levels requires an understanding of contributors to $\mathrm{CE}$ loss, including impurities.

Phosphorus originates mostly from alumina although it is found at higher concentrations in some other raw materials that enter the cells in smaller quantities. Phosphorus comes from alumina in the form of $\mathrm{AlPO}_{4}{ }^{3}$ Existence of other compounds in alumina such as $\mathrm{Al}\left(\mathrm{PO}_{3}\right)_{3}$, $\mathrm{Na}_{3} \mathrm{PO}_{4}$ and $\mathrm{Fe}_{2} \mathrm{P}$ have also been suggested. ${ }^{4,5}$

Before being fed to the cell, the alumina feedstock is used as an absorbant in the fume-treatment dry-scrubbers, which are standard at modern aluminum smelters. These units are installed in order to capture HF from the cell flue-gas, but the alumina absorbant captures and becomes enriched with other compounds as well, including phosphorous compounds. This may lead to accumulation of impurities in the cells, which raises concerns regarding the effect on important parameters in aluminum electrolysis including the CE. ${ }^{6-8}$

The influence of phosphorus on $\mathrm{CE}$ has been presented in a number of papers. ${ }^{9-12}$ Phosphorus can have many oxidation states from -3 up to +5 , and most probably it dissolves in the electrolyte in the oxidation state of +5 . $^{3}$

Both Solli ${ }^{9}$ and Deininger et al. ${ }^{12}$ added $\mathrm{P}_{2} \mathrm{O}_{5}$ and Thisted ${ }^{10}$ added $\mathrm{AlPO}_{4}$ to study effect of phosphorus in laboratory cells.

Deininger et al. ${ }^{12}$ proposed that below $1200 \mathrm{mg} / \mathrm{kg}$ phosphorus it will be reduced to three valent as follows:

$$
\mathrm{P}^{5+}+2 \mathrm{e}^{-}=\mathrm{P}^{3}
$$

The reduction to the elemental phosphorus occurs at higher concentrations:

$$
\mathrm{P}^{5+}+5 \mathrm{e}^{-}=\mathrm{P}^{0}
$$

Both these products $\left(\mathrm{P}^{3+}, \mathrm{P}^{0}\right)$ can be reoxidized at the anode. An earlier study of Kerouanton and Badoz-Lambling ${ }^{13}$ and Charlot et al. ${ }^{14}$ also

\footnotetext{
*Electrochemical Society Member.
}

${ }^{\mathrm{z}}$ E-mail: rauan@ru.is observed reduction of five valent phosphorus to three valent through a two electrons exchange. The reported results ${ }^{9-12}$ are in agreement with industrial observations ${ }^{6}$ (about $1 \%$ decrease in CE per $100 \mathrm{mg} / \mathrm{kg} \mathrm{P}$ ). It was concluded that the $\mathrm{CE}$ loss was a result of cyclic red-ox reactions which convey electric current without producing any aluminum.

Later Keppert ${ }^{15}$ motivated by the fact that phosphorus has a detrimental effect on CE studied the electrochemical behavior of phosphorus in cryolite melts by cyclic voltammetry and chronoamperometry. He reported that phosphorus reduction proceeds in two steps. The first reduction step, which is reversible and diffusion controlled is:

$$
\mathrm{PO}_{4}{ }^{3-}+2 \mathrm{e}^{-}=\mathrm{PO}_{3}{ }^{3-}+\mathrm{O}^{2-}
$$

The second reduction step is irreversible and proceeds simultaneously with aluminum reduction with following equation:

$$
\mathrm{PO}_{3}{ }^{3-}+2 \mathrm{e}^{-}=\mathrm{PO}_{2}{ }^{3-}+\mathrm{O}^{2-}
$$

The possibility of formation of elemental phosphorus was also considered. He concluded that the first step (Eq. 3) is the primary cathode reaction contributing to loss in CE. Although there is no solid evidence for the mechanism for reactions involving phosphorus impurities as a cause of loss in current efficiency, the concept of cyclic redox reactions seems to be the most plausible explanation.

A number of researchers have reported that phosphorus compounds are volatile in aluminum reduction cells. For instance, Böhm et al. ${ }^{7}$ published that $72 \%$ of phosphorus compounds escape in the gas phase. The more volatile the phosphorus, the more it will be recycled back with secondary alumina after dry scrubbing. Augood ${ }^{8}$ reported that $90 \%$ of phosphorus can be expected to leave as gas (gas/feed constant was equal to 0.91 ). However, Solli ${ }^{9}$ based his results on input concentrations of the phosphorus rather than analyzing the content in the electrolyte during the electrolysis. Thisted ${ }^{10}$ analyzed the phosphorus content in the electrolyte and reported that she observed a maximum deficit of phosphorus in the electrolyte close to $70 \%$. She concluded that it might have been due to inefficient addition through the anode conductor to the laboratory cell. The $\mathrm{AlPO}_{4}$ powder might have been expelled by the nitrogen gas coming out of the furnace. Haugland et al. $^{3}$, on the other hand, added phosphorus into an industrial cell and found that phosphorus decay over time was very small, indicating limited loss through a formation of volatiles.

In this work, these limitations in previous studies were addressed. The predetermined amount of phosphorus was mixed with electrolyte contents before the start of the experiment to avoid any losses through 


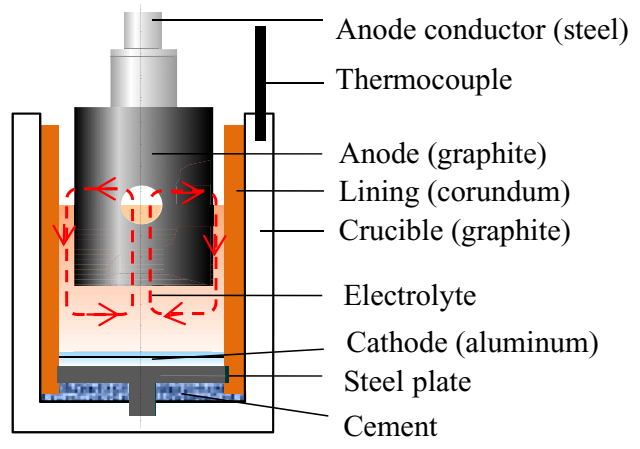

Figure 1. Schematic of the laboratory cell. The electrolyte circulation pattern is shown by arrows.

feeding. Moreover, the phosphorous content in the electrolyte was monitored during the electrolysis experiment to make sure that eventual depletion through formation of phosphorous containing volatiles was taken into account.

In this study, the results from Solli ${ }^{9}$ and Thisted ${ }^{10}$ at $0.8 \mathrm{~A} / \mathrm{cm}^{2}$ were used as a reference and $\mathrm{CE}$ measurements with their reported experimental conditions repeated for verification. As the industry pushes toward high amperage in existing aluminum reduction cells which may require higher current densities, $\mathrm{CE}$ experiments at a higher current density of $1.5 \mathrm{~A} / \mathrm{cm}^{2}$ were made. It is of interest for industry to know if the phosphorus effect persists at high current densities, and if the effect is either more or less significant at such conditions.

\section{Experimental}

All the experiment parameters were chosen to match Solli ${ }^{9}$ and Thisted. ${ }^{10}$ The experimental cell is located in a laboratory at NTNU/Sintef in Trondheim, Norway, and is similar to that used by Solli. ${ }^{9}$ The cell is used to determine CE for aluminum production during constant current electrolysis. Fig. 1 is a schematic illustration of the cell. The advantage of this type of cell is that it provides a good convective pattern and maintains an almost flat cathode surface by using a graphite anode with holes drilled perpendicular to each other and a steel cathode that is wettable by liquid aluminum.

First, a sintered alumina cylinder with diameter of $65 \mathrm{~mm}$ and length of $110 \mathrm{~mm}$ is placed inside a graphite crucible. The graphite crucible with a sintered alumina lining serves as the container for the molten electrolyte. Then, a steel pin $8 \mathrm{~mm}$ in diameter and $4 \mathrm{~mm}$ long is glued by carbon glue to the bottom of the crucible. This pin provides electrical contact between the steel cathode plate and the graphite crucible. Afterwards, the bottom of the crucible is cemented with cast alumina cement (Termomax, Borgestad Fabrikker, Norway containing $96 \mathrm{wt} \%$ of alumina and $3 \mathrm{wt} \% \mathrm{CaO}$ ) and left to dry inside a $473 \mathrm{~K}\left(200^{\circ} \mathrm{C}\right)$ furnace for 2 days. Alumina powder is then poured on top of the dehydrated cement. These layers should prevent contact of aluminum metal with the graphite crucible, which can result in aluminum loss and aluminum carbide formation. Next, a steel plate with diameter of $60 \mathrm{~mm}$ and thickness of $5 \mathrm{~mm}$ is put on top of the alumina powder to act as a wettable cathode material for the aluminum. Finally, the prepared powder electrolyte is poured on top of the steel plate. An electrolyte is composed of $\mathrm{AlF}_{3}(25.20 \mathrm{~g})$, $\mathrm{Na}_{3} \mathrm{AlF}_{3}$ (319 g), $\mathrm{CaF}_{2}$ (18.92 g), $\mathrm{Al}_{2} \mathrm{O}_{3}$ (15.13 g) corresponding to $\mathrm{CR}$ (molar ratio) of $\mathrm{NaF} / \mathrm{AlF}_{3}$ equal to 2.5 , with 4 wt $\% \mathrm{Al}_{2} \mathrm{O}_{3}$ and $5 \mathrm{wt} \% \mathrm{CaF}_{2}$. Aluminum phosphate $\left(\mathrm{AlPO}_{4}\right)$ was added as a source of phosphorous. All the listed chemicals were used from Merck with 99\% purity except handpicked natural cryolite from Greenland. The electrolyte mixture was identical for all experiment, changing only the phosphorous concentration, which was monitored by ICP analysis of samples taken at regular intervals during the experiment.

The cell is placed in a Pythagoras (mullite) tube inside the furnace. Two ends of the tube are closed with copper flanges, which are greased and sealed with rubber rings to ensure a gastight furnace. The stainless steel tube is connected to the graphite anode with a diameter of 52 $\mathrm{mm}$ and length of $70 \mathrm{~mm}$ and placed above the cell. The design of the anode is fitted with vertical holes and horizontal channels are to facilitate convection in the cell. The bottom of the anode has $10^{\circ}$ inclination up toward the center hole which will make gas bubbles move in the direction of the center hole.

Nitrogen gas is flushed with a flow rate of $0.2-0.3 \mathrm{dm}^{3} / \mathrm{min}$ through the furnace to prevent air burn of the cell. The system is water cooled where water is provided through tubes connected to the top and bottom of the furnace.

The thermocouple ( $\mathrm{Pt} / \mathrm{Pt} 10 \mathrm{Rh})$ is placed inside a slot in the crucible for the entire time of electrolysis and temperature readings are recorded. The temperature difference between the inside and outside of the electrolyte is recorded in the first experiment and the temperature is regulated accordingly. Moreover, voltage and current readings are also monitored and recorded. The current is supplied by a DC power supply. The cathodic current density is calculated by the total current divided by the cross-sectional area of the sintered alumina lining using the inner radius. The cross sectional area of sintered alumina is equal to $33.17 \mathrm{~cm}^{2}$. The furnace is connected to an electric heater, and the temperature is regulated by this heater. When the furnace has reached a temperature of $1253 \mathrm{~K}\left(980^{\circ} \mathrm{C}\right)$, the anode is immersed in the electrolyte until electrical contact is achieved. The immersion of the anode is repeated several times, and the contact points are marked on the steel tube. When the actual contact position is established, the anode tube is lowered an additional $2 \mathrm{~cm}$ from the contact position. Alumina additions are made manually every 15 minutes through a central steel tube screwed into the hollow anode, and the electrolyte was sampled at regular intervals for each experiment.

The duration of each experiment is aimed at producing the same amount of aluminum, so at high current densities, and correspondingly high total cell current, the duration would be shorter than at low current densities. The duration of the experiment therefore ranges from 2 to 4 hours. After termination of electrolysis, everything is switched off and left to cool down. Then the crucible is broken and the aluminum is cleaned mechanically and left in an aqueous solution of $\mathrm{AlCl}_{3} \cdot 6 \mathrm{H}_{2} \mathrm{O}$ at $298 \mathrm{~K}\left(25^{\circ} \mathrm{C}\right)$ for 30 minutes. $\mathrm{CE}$ is calculated by weighing the amount of deposited aluminum and comparing it to the theoretical amount calculated from Faraday's law by the following equation:

$$
\mathrm{CE}=\mathrm{m}_{\text {actual }} / \mathrm{m}_{\text {theoretical }}
$$

where $\mathrm{m}_{\text {actual }}$ is the produced aluminum and the $\mathrm{m}_{\text {theoretical }}$ is the theoretical maximum production of aluminum given by Faraday's laws and can be expressed by the equation: ${ }^{2}$

$$
\mathrm{m}_{\text {theoretical }}=(\mathrm{MIt}) /(\mathrm{z} F)
$$

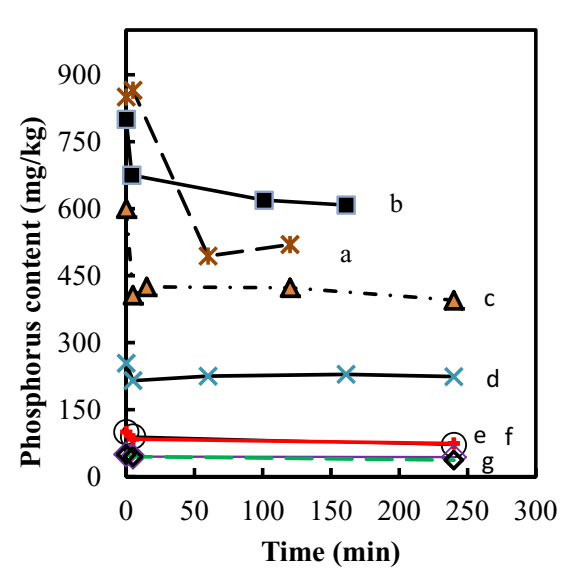

Figure 2. Phosphorus concentration change with time for different concentrations added at the beginning of the experiment ("a" is $850 \mathrm{mg} / \mathrm{kg}$, "b" -800 $\mathrm{mg} / \mathrm{kg}$, "c" $-600 \mathrm{mg} / \mathrm{kg}$, "d"-254 mg/kg, "e"-100 mg/kg, "f"-50 mg/kg, "g"-50 mg/kg). 


\begin{tabular}{|c|c|}
\hline $\begin{array}{l}\text { Input } \\
\mathrm{mg} / \mathrm{kg}\end{array}$ & $\begin{array}{l}\text { Average concentration in electrolyte } \\
\qquad \mathrm{mg} / \mathrm{kg}\end{array}$ \\
\hline 50 & 41.0 \\
\hline 50 & 39.3 \\
\hline 100 & 80.6 \\
\hline 100 & 79.1 \\
\hline 254 & 223.0 \\
\hline 254 & 230.0 \\
\hline 600 & 412.0 \\
\hline 800 & 634.0 \\
\hline 800 & 626.0 \\
\hline
\end{tabular}

where $\mathrm{F}=96485 \mathrm{C} \mathrm{mol}^{-1}$ is Faraday's constant, $\mathrm{M}$ is the molar mass, $\mathrm{Z}$ is the number of electrons involved in the electrode reaction, $\mathrm{I}$ is the current and $\mathrm{t}$ is the time.

Sample analysis.-High Resolution Inductive Coupled Plasma Mass Spectrometer (HR-ICP-MS) was used to analyze the samples for chemical composition. To prepare samples, 0.1 to $0.2 \mathrm{~g}$ of sample was digested in a solution composed of $5 \mathrm{ml} \mathrm{HCl}, 0.5 \mathrm{ml} \mathrm{HNO}_{3}$, and $0.5 \mathrm{ml} \mathrm{HF}$. The vial was heated on a heating block for 90 minutes at $343 \mathrm{~K}\left(70^{\circ} \mathrm{C}\right)$, and for the last 30 minutes the temperature was increased to $353 \mathrm{~K}\left(80^{\circ} \mathrm{C}\right)$. After cooling, the sample was diluted to $50 \mathrm{~mL}$ with MilliQ-water. The sample was further diluted 40 times before analyzing with ICP-MS.

\section{Results and Discussion}

Maintenance of constant phosphorus concentration.-The predetermined amount of phosphorus in the form of $\mathrm{AlPO}_{4}$ was mixed with the electrolyte contents before the start of the experiment. Samples for ICP analyses were taken at constant intervals during the experiment. Fig. 2 illustrates how the phosphorus concentration changed with time for different input contents during 4 hour electrolysis. As can be seen from it, amount of phosphorus added initially into the electrolyte dropped to some extent in the beginning, but subsequently it remained stable for the whole period. Therefore extra additions of phosphorus during the experiments were not required. It is not clear why the phosphorous is depleted only initially but later remains stable. The observed initial loss and then stability might indicate that part of the aluminum phosphate initially reacts into a volatile form but the remaining phosphate rapidly reacts with the electrolyte, into a more stable form, which does not form a volatile species. Another possible explanation is if phosphorus containing species have an affinity to the alumina or carbon surfaces present in the cell. To the extent that these results are transferable to industrial cells where the phosphorus content would be measured in the bath or metal, we use the analytical concentration in the interpretation of our results. After this behavior had been firmly established, only the first and last samples were analyzed by ICP, and only if needed were other samples taken in between and analyzed to establish the concentration in the electrolyte.

The results given in Table I show the average concentrations in the electrolyte measured by ICP as well as the initial amount of phosphorus in the mix.

By plotting the data presented in Table I, a plot of average concentration in the electrolyte as a function of the initially added amount can be constructed, which could be used to predict the expected concentration of phosphorus for a given added amount (Fig. 3).

Current efficiency.-The CE as a function of the average phosphorus concentration is presented graphically in Fig. 4. Tests with different concentrations of phosphorus in the electrolyte were run both at $0.8 \mathrm{~A} / \mathrm{cm}^{2}$ and $1.5 \mathrm{~A} / \mathrm{cm}^{2}$. The tests at a current density of 0.8 $\mathrm{A} / \mathrm{cm}^{2}$ were run for verification by repeating previous works done by Thisted $^{10}$ and Solli ${ }^{9}$ that used this current density in their work.

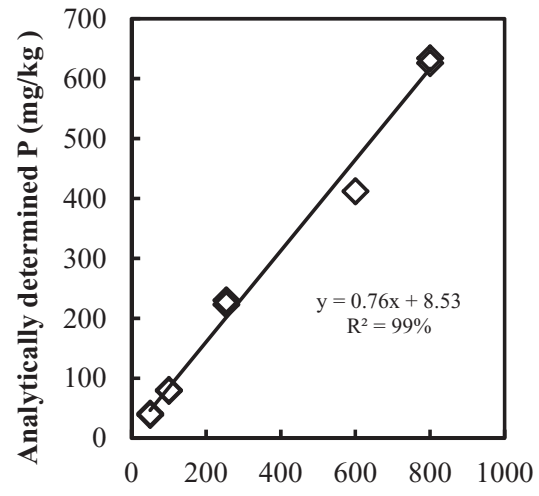

Input concentration $P(\mathrm{mg} / \mathrm{kg})$

Figure 3. Average concentration of phosphorus in the electrolyte analyzed by ICP at each input concentration.

As can be seen from Fig. 4, the reported results for the present study are in agreement with Solli ${ }^{9}$ and Thisted ${ }^{10}$ showing similar trendlines. Solli ${ }^{9}$ corrected his metal weight values by adding $0.33 \mathrm{~g}$ (equivalent to $+0.9 \%$ in $\mathrm{CE}$ ) to the metal produced after weighing the amount of deposited metal in every experiment to take into account metal losses through corrosion reactions and formation of carbide. More details are given in Solli's thesis. ${ }^{9}$ In the results presented in this work this procedure was not followed, which should lead to lower CE value by a constant $0.9 \%$ as compared to Solli's work. It is not clear weather Thisted followed Solli's procedure in adding $0.33 \mathrm{~g}$ assumed handling loss.

Based on added phosphorous amount rather than the chemical analysis, the CE reduction calculated for the present study is $0.51 \%$ $\pm 0.18 \%$ (Standard Deviation-SD) per $100 \mathrm{mg} / \mathrm{kg}$ of phosphorus increase at $0.8 \mathrm{~A} / \mathrm{cm}^{2}$, for a range in phosphorous concentration up to $630 \mathrm{mg} / \mathrm{kg}$. According to results from Thisted ${ }^{10}$ and Solli, ${ }^{9}$ the CE reductions are $0.51 \% \pm 0.3 \%(\mathrm{SD})$ and $0.52 \% \pm 0.17 \%(\mathrm{SD})$ per $100 \mathrm{mg} / \mathrm{kg}$ of phosphorus respectively. However, it should be noted that Thisted calculated the slope only up to $500 \mathrm{mg} / \mathrm{kg}$ in her original work, ${ }^{10}$ which gives $0.8 \%$ per $100 \mathrm{mg} / \mathrm{kg}$. She reported that effect of further phosphorus additions on $\mathrm{CE}$ is less pronounced at higher concentrations than $500 \mathrm{mg} / \mathrm{kg}$. Solli ${ }^{9}$ observed a flattening of the CE curve at phosphorous concentrations above $330 \mathrm{mg} / \mathrm{kg}$. Both authors speculated that this could be due to higher evaporation of phosphorus compounds at these concentrations.

Thisted reported that the average concentration of phosphorus in the electrolyte was 300 and $400 \mathrm{mg} / \mathrm{kg}$ for the added amount of 500 and $1000 \mathrm{mg} / \mathrm{kg}$ respectively. Solli ${ }^{9}$ did not measure the phosphorus content in the electrolyte. From the phosphorous concentrations shown in Fig. 2 an expected concentration in the electrolyte can be estimated from Fig. 3 for the experimental design and conditions in the present work. As Solli and Thisted used the same cell and similar

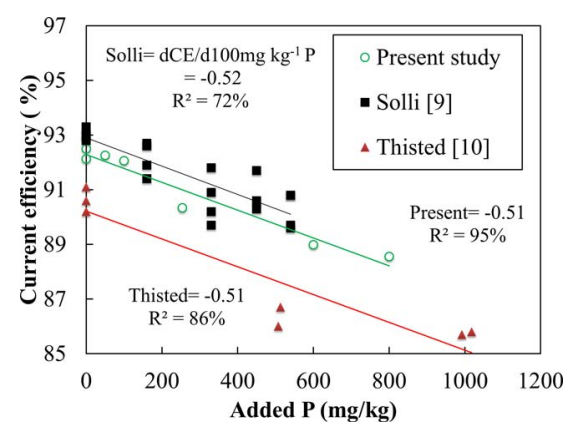

Figure 4. CE for aluminum deposition as a function of the added phosphorus at $0.8 \mathrm{~A} / \mathrm{cm}^{2}$. 


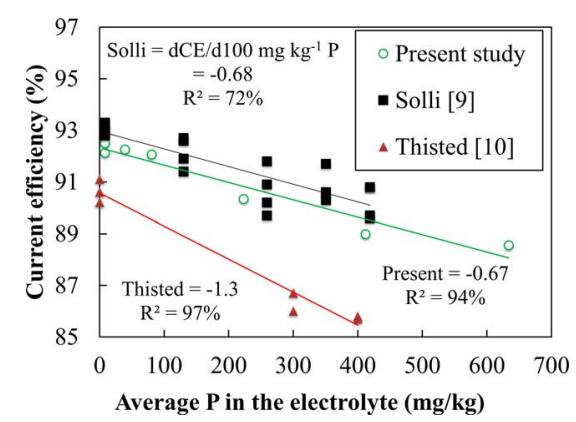

Figure 5. CE for aluminum deposition as a function of the phosphorus concentration in the electrolyte at $0.8 \mathrm{~A} / \mathrm{cm}^{2}$.

setting, this figure was used to deduce the actual concenteration in their electrolyte. This way $\mathrm{CE}$ as a function of deduced electrolyte phosphorous concentration could be plotted for their data, for comparison to the present work as shown on Figure 5.

As seen in Fig. 5, the present results show a reduction in the current efficiency at $0.8 \mathrm{~A} / \mathrm{cm}^{2}$ of $0.67 \% \pm 0.18(\mathrm{SD}) \mathrm{pr} .100 \mathrm{mg} / \mathrm{kg}$ increase in phosphorous concentration in the electrolyte over the whole range of concentrations studied. This corresponds well with Solli's ${ }^{9}$ result of $0.68 \% \pm 0.17(\mathrm{SD})$, while Thisted $^{10}$ is higher at $1.3 \%$ per $100 \mathrm{mg} / \mathrm{kg}$ of phosphorus in the electrolyte.

The long residence time of phosphorus in the electrolyte and the loss in CE observed in the results suggest that cyclic red-ox reactions are taking place due to the high number of phosphorus oxidation states. This has been discussed in literature. Phosphorus species are oxidized with $\mathrm{CO}_{2}$ on the anode and reduced by the metal at the cathode in a closed loop cycle until it leaves with the gas or through the metal. It is known that concentration gradient exists in the bath/metal boundary layer. The phosphorus concentration of $\mathrm{P}^{5+}$ decreased inside boundary layer as it is reduced to $\mathrm{P}^{3-}$. The concentration of $\mathrm{P}^{3-}$ will increase, but due to the high convection at larger distance at the metal, most of $\mathrm{P}^{3-}$ goes back to the bath and only small part to the metal. The $\mathrm{P}^{3-}$ undergoes same mechanism near the anode, where it will be oxidized to $\mathrm{P}^{5+} .16$

The $\mathrm{CE}$ as a function of the average phosphorus concentration at $1.5 \mathrm{~A} / \mathrm{cm}^{2}$ is presented graphically in Fig. 6. The initial hypothesis was that the effect of phosphorous would be less pronounced at higher current densities. This is because higher current density in the cell meant higher overall current and therefore more rapid aluminum production, while the rate of the cyclic red-ox reactions by the phosphorous species causing loss in CE is mass transfer controlled and not necessary much affected by the current density. The results were, however, that the effect of phosphorus is more pronounced at higher

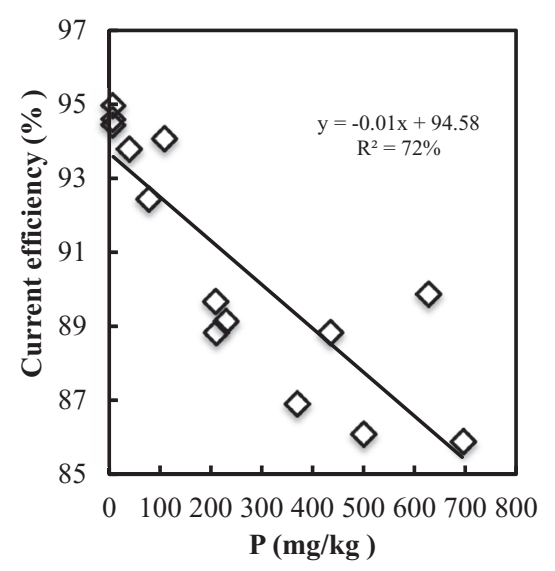

Figure 6. CE versus the phosphorus concentration in the electrolyte between $0-630 \mathrm{mg} / \mathrm{kg}$ concentration ranges at $1.5 \mathrm{~A} / \mathrm{cm}^{2}$.

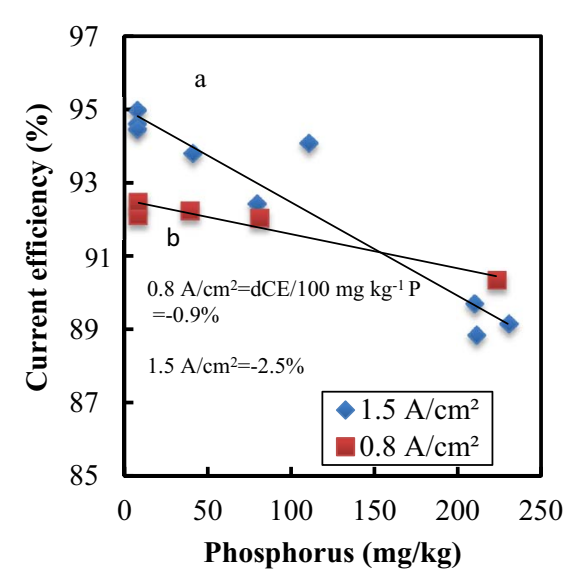

Figure 7. CE versus the phosphorus concentration in the electrolyte between $0-230 \mathrm{mg} / \mathrm{kg}$ concentration ranges at $0.8 \mathrm{~A} / \mathrm{cm}^{2}$ and $1.5 \mathrm{~A} / \mathrm{cm}^{2}$ (Regression lines "a" is for $0.8 \mathrm{~A} / \mathrm{cm}^{2}, \mathrm{y}=-0.009 \mathrm{x}+93.43, \mathrm{R}^{2}=93 \%$, " $\mathrm{b}$ " is for 1.5 $\left.\mathrm{A} / \mathrm{cm}^{2}, \mathrm{y}=-0.025 \mathrm{x}+95.92, \mathrm{R}^{2}=91\right)$.

current densities. Regression analysis of CE as a function of the phosphorous content at levels of up to $630 \mathrm{mg} / \mathrm{kg}$ gives a reduction of $1.1 \% \pm 0.21 \%$ per $100 \mathrm{mg} / \mathrm{kg}$ of phosphorus at $1.5 \mathrm{~A} / \mathrm{cm}^{2}$. This can possibly be attributed to increased stirring due to bubble formation and fluid dynamic effects, which lead to thinner diffusion layers and therefore more efficient mass transfer to the reaction planes. Thus, cyclic redox reactions are enhanced at higher current densities. Another possibility is that, at high current densities, the higher cathode potentials cause phosphorus to be reduced to lower oxidation states. The red-ox reactions with lower oxidation states can cause a larger $\mathrm{CE}$ loss due to the involvement of more electrons per cycle.

However, the concentration of phosphorus in industrial cells does not reach levels as high as $630 \mathrm{mg} / \mathrm{kg}$. If the slope is calculated for CE decrease in the range of industrial interest (from $0-220 \mathrm{mg} / \mathrm{kg}$, see Fig. 7), a reduction of $2.5 \% \pm 0.45 \%$ per $100 \mathrm{mg} / \mathrm{kg}$ of phosphorus is obtained at $1.5 \mathrm{~A} / \mathrm{cm}^{2}$. Doing the same estimate for a lower current density $\left(0.8 \mathrm{~A} / \mathrm{cm}^{2}\right)$, a slope of $0.92 \% \pm 0.16 \%$ per $100 \mathrm{mg} / \mathrm{kg}$ of phosphorus is found.

\section{Conclusions}

The results reported in this paper indicate that the effect of phosphorus on $\mathrm{CE}$ in aluminum electrolysis is significantly more pronounced at high current densities than at moderate current densities. This can be attributed to enhanced mass transfer due to stirring induced by the higher current density. The reduction in CE per unit increase in phosphorous concentration in the bath is also more pronounced at relatively low levels of contamination, and the effect seems to reach some sort of saturation at high levels. To be more specific, at relatively low phosphorus contents of up to $220 \mathrm{mg} / \mathrm{kg}$, a reduction in CE of $2.5 \% \pm 0.22 \%$ is observed per $100 \mathrm{mg} / \mathrm{kg}$ of phosphorus at $1.5 \mathrm{~A} / \mathrm{cm}^{2}$, while at $0.8 \mathrm{~A} / \mathrm{cm}^{2}$ it gave $0.92 \% \pm 0.17 \%$ per $100 \mathrm{mg} / \mathrm{kg}$ of phosphorus for the same range of concentrations. Trendlines over a range of up to $630 \mathrm{mg} / \mathrm{kg}$ in phosphorous concentration show a reduction of $1.1 \% \pm 0.22 \%$ per $100 \mathrm{mg} / \mathrm{kg}$ of phosphorus at $1.5 \mathrm{~A} / \mathrm{cm}^{2}$, while at $0.8 \mathrm{~A} / \mathrm{cm}^{2}$ the slope is $0.67 \% \pm 0.17 \%$. Thus, the effect of phosphorous levels out at a higher concentration of the contaminant, but remains more pronounced at a high current density as compared to moderate current densities. Also, studies of the effect of phosphorous on operational parameters, such as $\mathrm{CE}$, should include sampling and analysis for correct concentration values. It was established that although phosphorous concentrations in the bath are relatively stable for the duration of the experiments reported in this paper, it does not conform to the values derived from the initial additions of phosphate. In this case $76 \%$ of the added phosphorus was consistently retained in the electrolyte, but this is likely to be dependent on experimental conditions. 


\section{Acknowledgments}

Funding for this work was provided by Alcoa Fjarðaál and HRV Engineering. Assistance from Manolescu and Sintef staff is gratefully acknowledged.

\section{References}

1. M. Tangstad (ed): Metal Production in Norway, p. 28, Akademika Publishing, Trondheim (2013).

2. K. Grjotheim and H. Kvande, Introduction to Aluminum Electrolysis, p.146, Aluminum-Verlag GmbH, Düsseldorf, Germany (1993).

3. E. Haugland, G. M. Haarberg, E. Thisted, and J. Thonstad, in Light Metals 2001, J. L. Anjier, Editor, p. 549, The Minerals, Metals \& Materials Society (TMS), Warrendale, PA (2001).

4. V. Daněk, M. Chrenková, A. Silný, G. M. Haarberg, and M. Staš, Canadian Metallurgical Quarterly, 38(3), 149 (1999).

5. L. P. Lossius and H. A. Øye, in Light Metals 1992, E. Cutshall, Editor, p. 249, The Minerals, Metals \& Materials Society (TMS), Warrendale, PA (1992).
6. H. Albers and H. C. Wrigge, in 8th International Congress of ICSOBA, p. 485 (1997).

7. E. Böhm, L. Reh, V. Sparwald, and G. Winkhaus, in Light Metals 1976, S. R. Leavitt, Editor, p. 509, The Minerals, Metals \& Materials Society (TMS), Warrendale, PA (1976).

8. D. R. Augood, in Light Metals 1980, C. J. McMinn, Editor, p. 413, The Minerals, Metals \& Materials Society (TMS), Warrendale, PA (1980).

9. P. A. Solli, , Norwegian University of Science and Technology, Trondheim, Norway, 1993, ISBN 82-7119-477-1.

10. E. W. Thisted, Ph.D. thesis, Norwegian University of Science and Technology, Trondheim, Norway, 2003, ISBN 82-471-5603-2.

11. Å. Sterten, P. A. Solli, and E. Skybakmoen, J. Appl. Electrochem., 28, 781 (1997).

12. L. Deininger and J. Gerlach, Metall, 33, 131 (1979).

13. A. Kerouanton and J. Badoz-Lambling, Revue de Chimie Minerale, 11, 223 (1974).

14. G. Charlot, J. Badoz-Lambling, P. Homsi, and V. Plichon, J. Electroanal. Chem., 75, 665 (1977).

15. M. Keppert, Ph.D. thesis, Norwegian University of Science and Technology, Trondheim, Norway, 2006, ISBN 82-471-8275-0.

16. A. Solheim, in Light Metals 2016, E. Williams Editor, p. 371, The Minerals, Metals \& Materials Society (TMS), Warrendale, PA (2016). 